\title{
Effect of Socio-Demographic Factor and Democratic Leadership on Village Midwife Performance in IUD Contraceptive Service in Jombang District, East Java
}

\author{
Ratna Dewi Permatasari'), Uki Retno Budihastuti²), Didik Tamtomo ${ }^{3)}$ \\ ${ }^{1)}$ Masters Program in Public Heath, Sebelas Maret University \\ 2) Department of Obstetric and Gynecology, Dr. Moewardi Hospital , Surakarta \\ 3)Department of Anatomy, Faculty of Medicine, Sebelas Maret University
}

\begin{abstract}
Background: The threat of population explosion in Indonesia is real. Long-term contraception program is an alternative strategy for controlling population growth rate. The slowering achievement of IUD contraceptive target for the last two years has become a central concern at the District Health Office Jombang, East Java. Sub-optimal quality of IUD contraceptive service, high drop-out rate, high unmet-need, and unsystematic family planning reporting and recording, are assumed to be the causes of the under-achievement. This study aimed to examine the effect of sociodemographic factor and democratic leadership on village midwife performance in IUD contraceptive service in Jombang District, East Java.

Subjects and Method: This was an analytic observational study with cross-sectional design. It was conducted in 12 community health centers in Jombang District, East Java, from March to May 2017. A sample of 120 women of reproductive age was selected for this study by simple random sampling. The dependent variable was village midwife performance. The independent variables were knowledge, self-efficacy, compensation, democratic leadership, and work motivation. The data were collected by a pre-tested questionnaire, and were analyzed by path analysis model.

Results: Midwife performance was positively affected by higher education $(b=5.19 ; \mathrm{SE}=0.53$; $\mathrm{p}<0.001)$, stronger work motivation $(\mathrm{b}=0.48 ; \mathrm{SE}=0.07 ; \mathrm{p}<0.001)$, better knowledge $(\mathrm{b}=0.21$; $\mathrm{SE}=0.08 ; \mathrm{p}=0.006)$, stronger self-efficacy $(\mathrm{b}=0.18 ; \mathrm{SE}=0.08 ; \mathrm{p}=0.023)$, and democratic leadership $(b=0.14 ; S E=0.05 ; p=0.008)$. Self-efficacy was affected by education $(b=1.16 ; S E=0.62 ; p=0.063)$, knowledge $(b=0.35 ; \mathrm{SE}=0.08 ; \mathrm{p}<0.001)$, democratic leadership $(b=0.23 ; \mathrm{SE}=0.04 ; \mathrm{p}<0.001)$. Work motivation was affected by compensation ( $b=0.65 ; \mathrm{SE}=0.16 ; \mathrm{p}<0.001)$, democratic leadership ( $b=0.31 ; \mathrm{SE}=0.07 ; \mathrm{p}<0.001)$, knowledge $(b=0.29 ; \mathrm{SE}=0.09 ; \mathrm{p}<0.001)$, and self-efficacy $(\mathrm{b}=0.17 ; \mathrm{SE}=0.09 ; \mathrm{p}=0.058)$.
\end{abstract}

Conclusion: Midwife performance was positively affected by education, work motivation, education, self efficacy, and democratic leadership.

Keywords: midwife performance, socio-demographic factor, democratic leadership, IUD contraceptive, family planning.

\section{Correspondence:}

Ratna Dewi Permatasari. Masters Program in Public Heath, Sebelas Maret University, Jl. Ir. Sutami 36 A, Surakarta 57126, Central Java. Email: wahib.rifai81@gmail.com. Mobile: +6281334059159.

\section{BACKGROUND}

Population growth that remains high becomes the primary demographic problem faced by Indonesia. The higher population growth rate is, the bigger effort our government should conduct to sustain people's welfare. And the effort is by implementing
Family Planning (Sulistyawati, 2011). Family Planning program is an integrated part of national development program and aims to improve the quality of life of Indonesian people (Renstra BKKBN, 2015).

The success of Family Planning program refers to the decreasing TFR (Total Fertility Rate) and the increasing Contra- 
ception Prevalence Rate (CPR). In Medium-Term Development Plan 2014 CPR was beyond its target (60.1\%) with its attainment of $61.9 \%$ (Kemenkes, 2014). Strategic Objective Performance Indicator of National of National Demography and Family Planning Board (BKKBN) 2015-2019 also mentions the decreasing TFR on Women of Reproductive Age (15-49 years) in 2015 has reached 2.37 from 2.6 in 2014. The achievement was dominated by Family Planning participation of non Long Term Contraceptive Method that was still high compared to the use of Long Term Contraceptive Method which is more practical and accessible. The use of devices and drugs of Short Term Contraceptive Method keeps on escalating from $46.5 \%$ to $47.3 \%$, meanwhile Long Term Contraceptive Method is likely to be decreasing from $10.9 \%$ turns to $10.6 \%$ (Renstra BKKBN, 2015).

Health Office of Jombang Regency in this matter Family Health Section reserves working program to improve active Family Planning coverage especially IUD Long Term Contraceptive Method. Considering that the 2015 coverage of active participants of Family Planning in Jombang Regency reached $70.0 \%$, that was increasing from $68.3 \%$ in 2014, however it was still below the national target of Family Planning coverage that was $80 \%$. Furthermore there was decreasing number of active contraceptive IUD users from $7.40 \%$ turned to $7.20 \%$ in 2015. According to Jombang BKKBN data from Minimum Service Standard of Family Planning and Family Welfare (SPM OB-KS) stated that the target of IUD Long Term Contraceptive Method was 21.2\% in 2016 and for the attainment it was only $8.9 \%$ that it was still far from the determined target. It was generated by numerous factors among others were IUD service in Jombang Regency that was not optimal, high rate of drop out, high rate of unmet need, and
Family Planning recording and reporting system that was less systematic in Jombang Regency (Profil Dinkes Jombang, 2015).

The quality of contraceptive services is the result of midwives' performance that is achieved in conducting contraceptive services. A midwife's behaviors will influence her performance in conducting IUD service to mothers. The low targeted coverage of IUD Long Term Contraceptive Method is generated by a lot of factors, one of them is the village midwives' lack of participation in giving IUD services in village birth centers (Polindes). The low performance of midwives in the effort to improve the attainment of IUD coverage is assumed to be related to various factors namely socio demographic factor, and psychological factor also leadership factor within organization. (Gibson et al., 1987 in Ilyas, 2008) states that there are three variables that influence an individual performance, they are individual characteristic, organization characteristics, psychological characteristics.

A study by Merrill et al., (2013) States that service access is one of the factors that influence the use of contraceptive methods including IUD. The accessibility of good healthcare service, either the price, distance, and time of service is one of the matters that influence someone to utilize healthcare service (Kusumastuti et al., 2013). Various reasons that determine the administration of contraceptives services greatly depends on the midwives. Anggasari et al., (2013) finds that motivation, sttitude, and perception of leadership are related to the performance of midwives in IUD contraceptive service. Tampi (2014) mentions a significant relationship between leadership and motivation toward employees' performance.

Midwife as one of the providers under Health Ministry is the closes party to prospective acceptors since she is the first ser- 
vice provider who handles counseling up to contraceptives insertion. In which the authority in conducting contraceptive services is regulated in Ministry of Health's Regulation No. 1464/MENKES/PER/2010. Considering midwives' substantial role as the provider in contraceptive service, therefore midwives performance greatly influence the quality of IUD contraceptive service (BKK$\mathrm{BN}, 2010$ ).

The study aimed to analyze the effect of socio demographic factor and leadership perception toward village midwives' performance in IUD contraceptive service in Jombang Regency.

\begin{tabular}{l}
\hline SUBJECTS AND METHOD \\
\hline 1. Design of the Study \\
The method used in the study was analytic \\
observational study, with cross sectional \\
approach design. The study was conducted \\
during March- May 2017 in 12 Community \\
Health Centers within working area of \\
Jombang Regency, East Java
\end{tabular}

\section{Population and Sample}

Population in the study was the entire village midwives under the working area of Community Health Centers in Jombang Regency. Sample of quantitative study consisted of 120 subjects. Sampling technique used in quantitative study was simple random sampling that is choosing sample by selecting sample randomly, that samples reserve the same opportunity to be chosen as study subjects (Murti, 2013).

\section{Variables of the Study}

The dependent variable was midwife performance. Independent variables were knowledge, self eficacy, level of education, compensation, democratic leadership, working motivation.

\section{Operational Definition}

The operational definition of knowledge variable was the illustration of village midwife's understanding toward IUD contra- ceptive service by asking questions related to IUD contraceptive service..

Self efficacy was self assurance and self confidence of village midwife toward the ability to do IUD contraceptive service.

Level of education was the last level of education that was finished by midwife and could be proven by diploma certificate/ certificate of qualification. Compensation/ reward was awarding appreciation on behalf of the services, given to village midwife by her superior either in a form of financial or promotion.

Democratic leadership was leadership method that was implemented by the Head of Community Health Center in affecting midwife's behaviors with determined indicators. Working motivation was an encouragement or good spirit that arise from within as well as the influence of environment to conduct an activity/ duty as village midwife to accomplish working achievement that was the improvement of IUD contraceptive attainment.

Midwife performance was the result of working attainment of village midwife in IUD contraceptive service in accordance with her responsibility and target in a form of the improvement of active IUD contraceptive attainment.

\section{Data Analysis}

Based on the reliability test of item - total correlation it was found that the measuring of knowledge, self efficacy, level of education, compensation/reward, democratic leadership, working motivation, and midwife performance variables with $\mathrm{r} \geq 0.20$, and Cronbach's Alpha $\geq 0.70$, therefore all question items were asserted as reliable. The result of reliability test on questionnaires was presented in Table 1 .

For the sake of data analysis, the categorical data was shifted to dichotomy on level of education variable. Level of education associate's degree (D-III) of midwifery 
was given code $\mathrm{o}$ and bachelor's degree variate analysis used path analysis.

(DIV) of midwifery was given code 1 . Multi-

Tabel 1. The result of reliability test

\begin{tabular}{lcc}
\hline \multicolumn{1}{c}{ Variables } & Item Total Correlation (r) & Alpha Cronbach \\
\hline Knowledge & $\geq 0.34$ & 0.85 \\
Self Efficacy & $\geq 0.50$ & 0.87 \\
Compensation/ reward & $\geq 0.53$ & 0.86 \\
Democratic leadership & $\geq 0.51$ & 0.94 \\
Working motivation & $\geq 0.47$ & 0.92 \\
Midwife performance & $\geq 0.49$ & 0.93 \\
\hline
\end{tabular}

\section{RESULT}

The characteristics dimension of 120 village midwives were observed based on age, last education, working period, marital status, employment status, the distance of village birth center to community health center. Table 2 showed that out of 120 subjects of the study $82.5 \%$ were $\geq 30$ years; $81 \%$ had bachelor's degree (D-IV) of midwifery; $61 \%$ had worked for $\geq 10$ tahun, $87.5 \%$ were married, $69 \%$ were civil servants, $73 \%$ travelled $<10 \mathrm{~km}$ form village birth center to Community Health Center

Table 2. Characteristics of the study subjects

\begin{tabular}{llcc}
\hline Characteristics & \multicolumn{1}{c}{ Criteria } & n & \% \\
\hline Age & $<$ 30 years & 21 & 17.5 \\
& $\geq$ 30 years & 99 & 82.5 \\
Last Education & Associate's Degree(D-III)of Midwifery & 23 & 19.0 \\
& Bachelor's Degree (D-IV) of Midwifery & 97 & 81.0 \\
Working period & $<10$ years & 47 & 39.0 \\
& $\geq 10$ years & 73 & 61.0 \\
Marital status & Single & 15 & 12.5 \\
& Married & 105 & 87.5 \\
Employment status & Temporary employee & 37 & 31.0 \\
& Civil Servant & 29 & 69.0 \\
Distance of Village Birth Center to & $<10$ km & 88 & 73.0 \\
Community Health Center & $\geq 10$ km & 32 & 27.0 \\
\hline
\end{tabular}

Table 3. Univariate analysis of the variables of the study

\begin{tabular}{lccccc}
\hline Variables & n & Mean & SD & Min. & Max. \\
\hline Knowledge & 120 & 7.13 & 3.11 & 1 & 11 \\
Self Efficacy & 120 & 9.84 & 3.33 & 2 & 14 \\
Compensation/ reward & 120 & 7.91 & 3.11 & 2 & 12 \\
Democratic leadership & 120 & 18.87 & 7.37 & 4 & 28 \\
Working motivation & 120 & 14.26 & $5 \cdot 73$ & 3 & 22 \\
Midwife performance & 120 & 16.60 & 6.59 & 2 & 24 \\
\hline
\end{tabular}

The result of statistical descriptive of continuous data in a form of knowledge, self efficacy, compensation/ reward, democratic leadership, working motivation of village midwife, and midwife performance can be observed in Table 3. Through the table we can find out that each variable had relatively small data diversity. Mean represented the average value, whereas standard deviation (SD) value represented how di- 
verged the data were. Small SD was an indi-

cation that the data were representative.

Table 4. Bivariate analysis on the effect of knowledge, self efficacy, level of education, compensation/ reward, democratic leadership, working motivation toward village midwife performance in IUD contraceptive service

\begin{tabular}{lcc}
\hline Independent Variables & $\mathbf{r}$ & $\mathbf{p}$ \\
\hline Knowledge & 0.87 & $<0.001$ \\
Self Efficacy & 0.89 & $<0.001$ \\
Level of Education & 0.89 & $<0.001$ \\
Compensation/ reward & 0.94 & $<0.001$ \\
Democratic leadership & 0.94 & $<0.001$ \\
Working motivation & 0.96 & $<0.001$ \\
\hline
\end{tabular}

Table 4 showed that $(\mathrm{r}=0.87, \mathrm{p}<.001)$, self efficacy $(\mathrm{r}=0.89, \mathrm{p}<0.001)$, education $(\mathrm{r}=$ $0.89 ; \mathrm{p}<0.001)$, compensation/reward $(\mathrm{r}=$ o.94; $\mathrm{p}<0.001)$, democratic leadership ( $\mathrm{r}=$
0.94; $\mathrm{p}<0.001)$ and working motivation $(\mathrm{r}=0.96 ; \mathrm{p}<0.001)$ had positive effect toward village midwife performance and statistically significant.

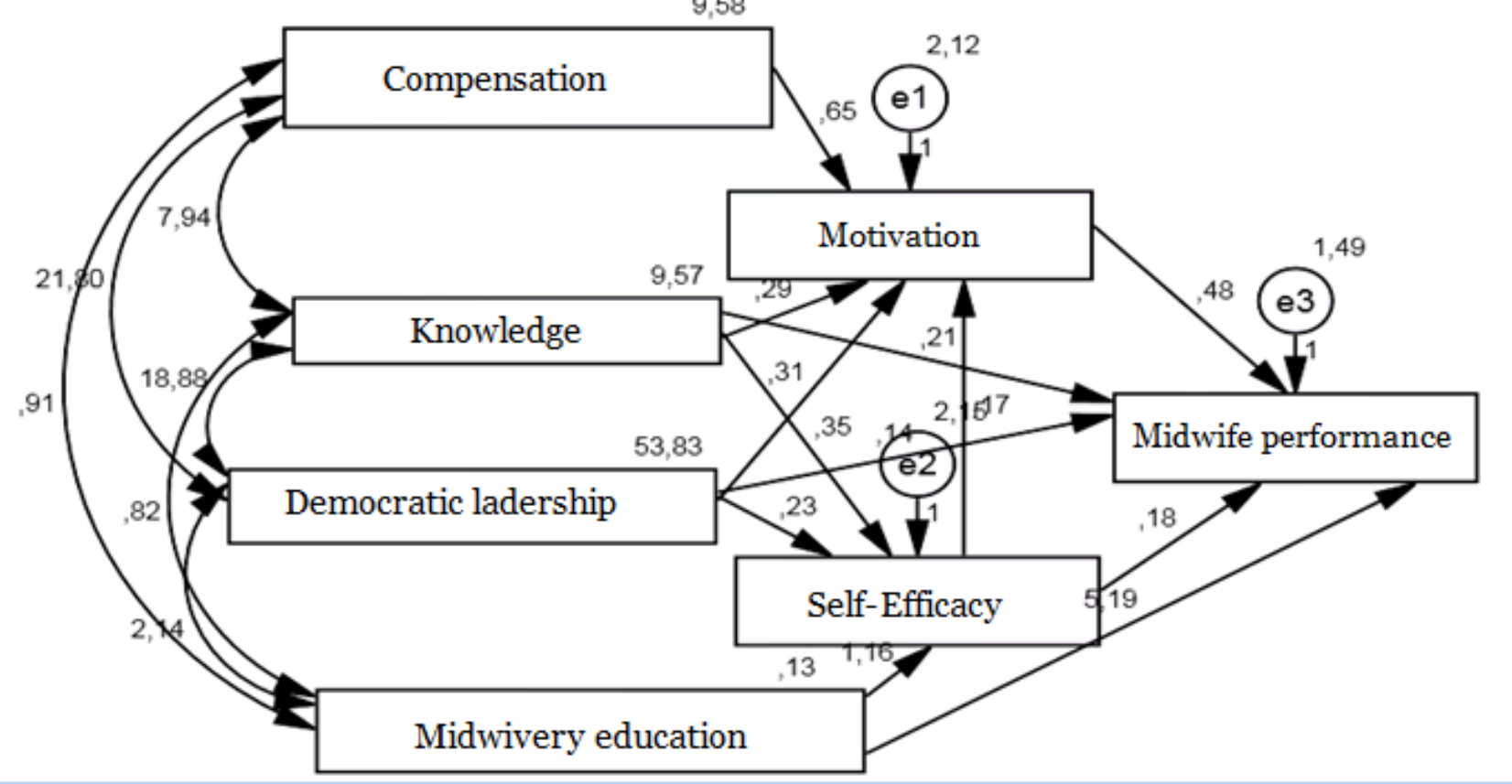

Figure 1. Structural model of path analysis

Figure 1 showed the structural model after an estimation was conducted by using $I B M$ SPSS AMOS 20, therefore it obtained values as it was presented in the figure. The indicators that showed the conformity of path analysis model such as in Table 5 also showed the occurrence of goodness of fit measure that it obtained the result of fit index CMIN by 4.94 with $\mathrm{p}=0.176>0.05$; $\mathrm{NFI}=0.99 \geq 0.90$; CFI $1.00 \geq 0.90$; GFI $0.99 \geq 0.90 ;$ RMSEA $=0.07 \leq 0.08$ which meant the empiric model met the determined criteria and it was declared as in accordance with empirical data.

From Table 5 it can be discovered that midwife performance was directly affectedby democratic leadership, level of education, knowledge, self efficacy, and working motivation.

Each one unit increase of democratic leadership will increase midwife performance by 0.14 unit $(b=0.14 ; \mathrm{SE}=0.05 ; \mathrm{p}=$ 
0.008). Each one unit increase of level of education will increase midwife performance by 5.19 unit $(b=5.19 ; \mathrm{SE}=0.53 ; \mathrm{p}$ $<0.001)$. Each one unit increase of

Table 5. The result of path analysis

\begin{tabular}{|c|c|c|c|c|c|c|}
\hline \multicolumn{2}{|c|}{ Dependent Variables } & Independent Variables & $\mathbf{b}^{*}$ & SE & $\mathbf{p}$ & $\boldsymbol{\beta}^{* *}$ \\
\hline \multicolumn{7}{|c|}{ Direct Effect } \\
\hline Performance & $\leftarrow$ & Democratic leadership & 0.14 & 0.05 & 0.008 & 0.16 \\
\hline Performance & $\leftarrow$ & Level of education & 5.19 & 0.53 & $<0.001$ & 0.29 \\
\hline Performance & $\leftarrow$ & Knowledge & 0.21 & 0.08 & 0.006 & 0.10 \\
\hline Performance & $\leftarrow$ & Self efficacy & 0.18 & 0.08 & 0.023 & 0.09 \\
\hline Performance & $\leftarrow$ & Working motivaton & 0.48 & 0.07 & $<0.001$ & 0.42 \\
\hline \multicolumn{7}{|l|}{ Indirect Effect } \\
\hline Self efficacy & $\leftarrow$ & Level of education & 0.31 & 0.62 & 0.063 & 0.13 \\
\hline Self efficacy & $\leftarrow$ & Democratic leadership & 0.16 & 0.04 & $<0.001$ & 0.50 \\
\hline Self efficacy & $\leftarrow$ & Knowledge & 0.35 & 0.08 & $<0.001$ & 0.33 \\
\hline Working motivation & $\leftarrow$ & Compensation/ Reward & 0.65 & 0.16 & $<0.001$ & 0.35 \\
\hline Working motivation & $\leftarrow$ & Democratic leadership & 0.31 & 0.07 & $<0.001$ & 0.40 \\
\hline Working motivation & $\leftarrow$ & Self Efficacy & 0.17 & 0.09 & 0.058 & 0.10 \\
\hline $\begin{array}{l}\text { Working motivation } \\
\text { Model Fit }\end{array}$ & $\leftarrow$ & Knowledge & 0.29 & 0.09 & $<0.001$ & 0.16 \\
\hline \multicolumn{7}{|c|}{$\mathrm{CMIN}=4.94 \mathrm{p}=0.176(>0.05)$} \\
\hline \multicolumn{7}{|c|}{$\mathrm{NFI}=0.99(\geq 0.90)$} \\
\hline \multicolumn{7}{|c|}{$\mathrm{CFI}=1.00(\geq 0.90)$} \\
\hline \multicolumn{7}{|c|}{ GFI $=0.99 \quad(\geq 0.90)$} \\
\hline \multicolumn{7}{|c|}{$\mathrm{RMSEA}=0.00(\leq 0.08)$} \\
\hline
\end{tabular}

Each one unit increase of self efficacy will increase midwife performance by 0.18 unit $(b=0.18 ; \mathrm{SE}=0.08 ; \mathrm{p}=0.023)$. Each one unit increase of working motivation will increase midwife performance by 0.48 unit $(b=0.48 ; \mathrm{SE}=0.07 ; \mathrm{p}<0.001)$.

Self efficacy was affected by level of education, democratic leadership, and knowledge. Each one unit increase of level of education will increase self efficacy by 1.16 unit $(b=0.16 ; \mathrm{SE}=0.62 ; \mathrm{p}=0.063)$. Each one unit increase of democratic leadership will increase self efficacy by 0.23 unit $(b=0.23 ; \mathrm{SE}=0.04 ; \mathrm{p}<0.001)$. Each one unit increase of knowledge will increase self efficacy by 0.35 unit $(b=0.35 ; \mathrm{SE}=0.08 ; \mathrm{p}<$ 0.001).

Working motivation was affected by compensation/reward, democratic leader- knowledge will increase midwife performance by 0.21 unit $(b=0.21 ; \mathrm{SE}=0.08 ; \mathrm{p}=$ 0.006). ship, self efficacy, knowledge. Each one unit increase of compensation/reward will increase working motivation by 0.65 unit $(b=0.65 ; \mathrm{SE}=0.16 ; \mathrm{p}<0.001)$. Each one unit increase of democratic leadership will increase working motivation by 0.31 unit $(b=0.31 ; S E=0.07, p<0.001)$. Each one unit increase of self efficacy will increase working motivation by 0.17 unit $(b=0.17, S E=$ o.09, $\mathrm{p}=0.058)$. Each one unit increase of knowledge will increase working motivation by 0.29 unit $(b=0.29 ; \mathrm{SE}=0.09, \mathrm{p}<0.001)$.

\section{DISCUSSION}

1. The Effect of Democratic Leadership toward midwife performance in IUD contraceptive service

There was a positive correlation between democratic leadership with village midwife 
Journal of Health Policy and Management (2017), 2(1): 16-27

https://doi.org/10.26911/thejhpm.2017.02.01.02

performance and statistically significant. The leadership is a competence dimension that determines employee's performance in attaining success of an organization (Sunyoto, 2013).

Democratic leadership style is particularly appropriate to be implemented in an organization, in this matter is Community Health Center, since it includes the element of influencing a group of people or subordinate to work together by maximizing the ability being possessed, exploring innovation and creativity, listening to subordinate's opinions, and suggestion to attain the intended purpose.

Mardiana (2014) measures the democratic leadership life style toward employee performance and it shows the occurrence of significantly positive relationship, therefore democratic leadership style should be sustained so that the employee performance can also be sustained or even enhanced. $82.5 \%$ out of the research subjects aged $\geq 30$ years old. Age is related to the improvement of midwife performance, some of the community considers age factor is a particular appeal to get healthcare service since most of mothers who visit healthcare facilities will get psychological reassurance if they are interacted with more mature midwives. According to Hurlock in Wawan dan Dewi (2010) the more mature someone's age and power will be likely to be more established in thinking and working.

Democratic leadership indirectly affects the improvement of employee working motivation. The achievement of a Head of Community Health Center in mobilizing village midwives to attain performance improvement greatly depends on the internal factor such as the occurrence of needs, intention, intended accomplishment, encouragement, responsibility toward the duty. The external factors are affected by supervision conducted by the superior, salary/ wages given, working condition/ environment, policy, the occurrence of recognition (Uno, 2011). Motivation positively and significantly affect employee performance . the higher the motivation is, the higher employee performance will be, and it works the other way around (Wijayanti, 2012).

Democratic leadership also indirectly affects self efficacy of midwife in improving performance. Others' persuasion, in this matter is leader/superior, affects individual self confidence and assurance so that gives impact to behavior. In the end behavior will affect individual working performance (Kinicky, 2008)

\section{The Effect of Level of Education toward midwife performance in IUD contraceptive service}

There was a positive correlation between level of education and midwife performance and statistically significant. Human resources have an important role in determining success within an organization. Capability is obtained from education process. Equipped with the education, village midwife will have the competence in handling problems related to her profession. High level of education will be formed as the future development because midwife with low level of education it will be difficult to develop and indirectly will complicate organization development. Veithzal dan Rivai (2013) state that performance is the unity of functions of employee's capability in this matter is obtained from education and motivation. $81 \%$ out of midwives' education is associate's degree (D-IV) of midwifery therefore it is relevant with the theory that high performance is obtained from high level of midwife education. Yulianthini et al., (2016) states that there is a significant effect of level of education toward performance. It can be concluded that high level of education is an important component in improving performance of an organization. 
Level of education indirectly affects self efficacy in performance improvement. Midwife with high level of education has better level of knowledge and skills hence has better self confidence in handling patients. Out of the subjects of the study who had high level of education most of them were midwives whose working period was $\geq 10$ years (61\%) and whose employment status was civil servants (69\%). Working period and acknowledgement for the employment status as civil servants will greatly affect someone's skill and self confidence. The longer the working period of a midwife, the more appropriate her experience, attitude and behavior to manage a case, make decisions in implementing a procedure will be. Therefore it they will bring high self confidence.

\section{The Effect of knowledge toward midwife performance in IUD contra- ceptive service}

There was a positive correlation between knowledge and midwife performance and statistically significant..

According to Green dan Kreuter (2005) knowledge one's predisposition factor to take action since behavior is based on knowledge. Yulianti (2014) shows that midwives with excellent working performance are likely to have excellent level of knowledge. Anggasari et al., (2013) states that good performance is possessed by midwife with excellent knowledge. Excellent knowledge and high skills will be the main asset in providing midwifery service.

Knowledge indirectly affects self efficacy. Sutriyani (2015) explains there is significant correlation between knowledge and the skill owned hence it affects one's self confidence therefore working professionalism will be improving, the better level of knowledge of a midwife, the more skilful she will be in handling midwifery cases. In accordance with Mangkunegara (2010) one's performance is a collaboration of capability, self confidence, effort, and opportunity that can be measured from generated the impact

Knowledge indirectly affects midwife's working motivation. Mappanganro et al., (2016) states that the encouragement from within (knowledge, attitude) affects one's motivation in working which later will improve performance. Excellent knowledge implicates to one's motivation to take action, deciding something at work. In accordance with Koopmans et al., (2011) conceptually individual performance is affected by among others is the knowledge possessed. Health workers who have excellent knowledge will have high motivation toward the procedures conducted at work, either motivation to make an achievement, to an award/reward at work, and recognition for their professionalism.

\section{The Effect of self efficacy toward midwife performance in IUD contra- ceptive service}

There was a positive correlation between self efficacy with village midwife performance and statistically came close to significant. Locke and Latham in Sulaeman (2016) state that performance is affected by some interconnected variables one of them is self efficacy. High midwife's self efficacy in working affects individual subjective opportunity to be successful at work, thus it affects the decision to try something new that is based on the confidence to be successful that can improve performance. Self efficacy is an individual perception ability to control his/her behavior. Self efficacy is an individual perception ability to control his/her behavior, the assurance of efficacy affects the purpose and aspiration, the stronger self efficacy is sensed, the higher purpose of motivation for him/herself and the more resolute the commitment will be (Sulaeman, 2016) It can be concluded that 
Journal of Health Policy and Management (2017), 2(1): 16-27

https://doi.org/10.26911/thejhpm.2017.02.01.02

efficacy affects working motivation, either when the employee is rewarded or when the employee herself shows her own capability. The degree of self efficacy is determined by the previous experiences, experiences that are acknowledged by other people, verbal persuasion, and emotional state. Perception that is owned by someone toward her capability to carry out a duty will improve the possibility for the duty to be successfully accomplished.

Self efficacy is related to the assurance that individual has the ability to conduct an expected action. Outcome expectation, self estimation that the behavior that is self conducted will attain certain result. The efficacy is self assessment, whether it is possible to conduct good or bad things, right or wrong, can or cannot be conducted as it is required. Efficacy is different from aspiration, since aspiration describes something ideal that should be (achieved), whereas efficacy describes the evaluation of self capability.

\section{The Effect of working motivation toward midwife performance in IUD contraceptive service}

There was a positive correlation between working motivation and village midwife performance and statistically came close to significant. Motivation functions as booster or reason for someone to do something. Nikpeyma (2014) mentions several factors that affect a health worker's performance such as individual factor, psychological factor, and organizational factor. The example of individual factor is the existence of motivation can improve efficiency, effectiveness, and performance thus can improve the service to society. Tawale (2011) states that motivation attempts the effort to optimize employee's potential to work well, willing to collaborate in promoting employee's performance, so that successfully attains and accomplishes the determined goals (Toode, 2015).

Strong or weak working motivation of an employee also determines her big or small achievement. The increasing working motivation makes someone reserves high spirit to give the best service to attain maximum performance. Widyaningrum (2011) mentions a correlation between employee's motivation variable and performance variable has the smallest significance level, there are some factors that affect between two variables of organization culture variable, commitment of the organization that play significant role within an organization.

Satisfaction toward the work is in line with the challenges she deals in providing serving for the society so that midwife can get the opportunity to attain excellent result and making accomplishment. A midwife should love her job, has the responsibility, and is given the opportunity by the government to improve her career such as promotion, training, and the most important thing is that midwife receive the recognition from the government for doing her duty well. The recognition or award given by the government can be in forms of letter of appreciation, reward, promotion and others.

A study made by Gamayanti et al., (2013), states the factor related to employee's motivation in Community Health Center in this matter includes village midwife, that is working condition, compensation, and relation between colleagues. Ahmed et al., (2010) mentions motivation factor plays an important role in improving employee working satisfaction and in the end in increasing employee performance.

Wijayanti (2012) states that motivation has positive effect and it is not significant toward employee performance, and also the other way around, the worse the mo- 
tivation is, the worse the employee performance will be.

Motivation can be used as a strategy to improve employee performance, since the effectiveness of employee performance depends on the motivation. The significant correlation between motivation and performance of village midwife will occur whenever conducive condition is established. Some reasons of decreasing motivation among village midwives are economy condition, less satisfying income, uncomfortable working environment, there are differences occur between village midwife and employee of Community Health Center, lack of appreciation from the leaders over working accomplishment made by midwife in the village because of the consideration that any routines conducted by midwife is her obligation to carry out and it is her part of consequence as a village midwife, so it needs conducive working relationship between village midwife with her shead and staff of Community Health Center, guidance from midwives coordinator and the head of Community Health Center in every activity or duty conducted by village midwife, as well as appreciation given to village midwife with excellent achievement in forms of commendation, promotion, educational allowance, also additional operational fund. The relationship between village midwife and society should be maintained well by means of soft skill improvement since excellent soft skill will affect midwife's acceptance among society and give impact to village midwife performance improvement.

There is an indirect effect of compensation/reward and motivation toward midwife performance. Compensation is closely related to the employment status. There are as many as $69 \%$ of of village midwives are Civil Servant.
Village midwife who reserve the system of compensation/ reward (in a form of service charge) evenly will be less motivated in carrying out her duty. Dissatisfaction will occur and lead to decreasing village midwife performance. It is different to distribution system of financial compensation (service charge) by using performance will generate self satisfaction from within so that it may improve village midwife performance.

A study by Fauzi (2014) finds that there is a significant correlation between compensation given with employee performance. The improving employee performance is affected by strong motivation to work based on the compensation in the form of financial or non financial which is fit to the employee, since the fulfilled compensation will reduce the concentration on other things outside the work. Someone who does not meet the competency to carry out a duty will bring out certain pressure, which in the end can generate low motivation because unconfident with the capacity she has (Edison et al., 2016).

Someone who has worked by devoting her effort, time, knowledge, and skills will expect the reward in either financial or non financial form. Salary or wage earned from a job may be used to motivate working achievement, with excellent reward employee will be motivated to attain the higher achievement level.

Based on the result of the study, it can be concluded that village midwife performance is affected by democratic leadership, level of education, knowledge, self efficacy and working motivation. Self efficacy is affected by level of education, democratic leadership, and knowledge. Working motivation is affected by compensation/ reward, democratic leadership, self efficacy and midwife's knowledge 


\section{REFERENCE}

Anggasari Y, Kartasurya M, Suparwati A (2013). Faktor-faktor yang berhubungan dengan kinerja bidan dalam pelaynan kontrasepsi IUD puskesmas Kota Surabaya. Jurnal Manajemen Kesehatan Indonesia, 1(2):106-114.

Ahmed I, Nawaz M, Iqbal N, Imran A, Saukhat Z, Usman A (2010). Effects of Motivational Factors on Employees Job Satisfaction a Case Study of University of the Punjab, Pakistan. International Journal Bussines of manajement CCSE, 5(3):70-80.

BKKBN (2010). Petunjuk Pelaksanaan Jaminan dan Pelayanan Keluarga Berencana Provinsi, Kabupaten dan Kota. Jakarta: BKKBN.

(2011). Kajian Implementasi Kebijakan Penggunaan Kontrasepsi IUD Policy Brief 3. Jakarta : Pusat Penelitian dan Pengembangan KB-KS. (2015). Rencana strategis Badan Kependudukan dan Keluarga Berencana Nasional. Jakarta.

(2015). Standart Pelayanan Minimal Dinas Pengendalian Penduduk dan Keluarga Berencana Kabupaten Jombang: Jombang Jawa Timur.

Dinas Kesehatan Kabupaten Jombang (2015). Profil kesehatan tahun 2015.

Edison E, Anwar Y, Komariyah I (2016). Manajemen sumber daya manusia. Bandung: Alfabeta.

Gamayanti FN, Amir YM, Indar (2013). Faktor yang berhubungan dengan motivasi kerja tenaga kesehatan di Puskesmas Banggae II Kabupaten Majene Provinsi Sulawesi Barat. Tesis. Universitas Hasanudin Makasar.

Green WL, Kreuter M (2005). Health Program Planning An Educational and Ecological Approadh Fourth Edition. New York: Mc Grew-Hill Companies
Ilyas (2008). Organisasi, Perilaku, Struktur, dan Proses. Jakarta: Binapura Aksara Publisher.

Kementrian Kesehatan RI (2014). Pusat Data dan Informasi Situasi dan Analisis Keluarga Berencana. Jakarta.

Kinicky, Kreitner, Robert (2008). Organizational Behavior. 8th Edition. Boston: McGraw-Hill.

Kirom B (2015). Mengukur kinerja pelayanan dan kepuasan konsumen: service Performance and satisfaction measurement (Cetakan ke 4). Bandung: Pustaka Reka Cipta.

Koopmans L, Bernaards CM, Hildebrandt HV, Schaufeli WB, Henrica CW, Beek AJ (2011). Conceptual Frameworks of Individual Work Performance A Systematic Review. American College of Occupational and Environmental Medicine. 53(8):856-866.

Kusumastuti, Purnami TC, Tjondrorini (2015). Analisis faktor- faktor yang berhubungan dengan perilaku pelayanan kontrasepsi oleh bidan di Kabupaten Kebumen. Jurnal Ilmiah Kesehatan Keperawatan: 11(2): 91103.

Mangkunegara PA (2010). Manajemen sumber daya manusia. Bandung: Remaja Rosdakarya.

Mappanganro A, Hardianti A (2016). Hubungan pengetahuan dan sikap dengan motivasi perawat dalam menerapkan prosedur pelaksanaan pemberian obat di Rumah Sakit Ibnu Sina YWUmi Makasar. Jurnal Ilmiah Kesehatan Diagnosis.2(9)1-9

Mardiana (2014). Pengaruh gaya kepemimpinan demokratis terhadap kinerja pegawai pada kantor sekretariat daerah Kota Samarinda. Jurnal Ilmu Pemerintahan. 2(1): 1802-1816.

Merrill MR, Aldana GS , Pope EJ, David AR, Carter CR, Jessica GJ, Whitmer 
WR (2013). Self-rated job performance and absenteeism according to employee engagement, health behaviors, and physical health. JOEM (American College of Occupational and Environmental Medicine): 55(1): 10-18.

Murti B (2013). Desain dan ukuran sampel untuk penelitian kuantitatif dan kualitatif di bidang kesehatan. Yogyakarta: Gadjah Mada University Press.

Nikpeyma N, Saeedi ZA, Azargashb E, Majd HA (2014). Problems of clinical nurse performance appraisal system-a qualitative study. Asian Nursing Research. 8: 15-22.

Sulistyawati A (2011). Pelayanan keluarga berencana. Jakarta: Salemba Medika.

Sunyoto D (2013). Teori, kuesioner dan analisa data perilaku organisasional. Yogyakarta: CAPS (Center for Academic Publishing Service).

Sulaeman S (2016). Pembelajaran model dan teori perilaku kesehatan konsep dan aplikasi. Surakarta: UNS Press.

Sutriyani T (2015). The influence of knowledge, skill and attitude to midwife professionalism of D IV midwife educator (bidan pendidik) student in Tribhuwana Tunggadewi University Malang. Journal of Health, medicine and Nursing, 18: 14-19.

Sutrisno E (2016). Manajemen sumber daya manusia. Jogjakarta: Prenada Media (Kencana).

Tampi JB (2014). Pengaruh gaya kepemimpinan dan motivasi terhadap kiner- ja karyawan pada PT. Bank Negara Indonesia, TBK (regional sales Manado). Journal Acta Diuma, 4(3)1:20.

Toode K (2015). Nurse's Work Motivation. Finlandia, University of Tampere. Dissertation.

Tawale EN, Budi W, Nurcholis G (2011). Hubungan antara motivasi kerja perawat dengan kecenderungan mengalami burnout pada perawat di RSUD Serui-Papua. Jurnal Insan. 13(2):7484.

Uno B (2011). Teori motivasi dan pengukurannya. Jakarta: Bumi Aksara.

Veithzal R (2013). Manajemen sumber daya manusia untuk perusahaan. Jakarta: Rajawali Pers.

Wawan, Dewi (2010). Teori pengukuran pengetahuan, sikap dan perilaku manusia. Nuha Medika. Yogyakarta.

Wijayanti SR, Widagdo L, Purnomo TC (2014). Analisis pelaksanaan konseling kontrasepsi oleh bidan di Wilayah Dinas Kesehatan Kota Surakarta. GASTER: 11(2):78-87.

Widyaningrum EM (2011). Influence of motivation and culture on organizational commmitmen and performance employee of medical services. Academic Research International. 3(1):228-235.

Yulianti E (2014). Faktor-faktor yang mempengaruhi kinerja bidan Puskesmas dalam penangganan ibu hamil risiko tinggi di Kabupaten Pontianak tahun 2012. Jurnal Ilmiah Bidan. 1(2):10-17. 